\title{
RESOURCE POTENTIAL FOR BIOGAS PRODUCTION IN UKRAINE
}

\author{
Lesia Pavliukh ${ }^{1, *}$, Sergii Boichenko ${ }^{1}$, Valeriya 0 nopa $^{1}$, Oksana Tykhenko $^{1}$, \\ Petro Topilnytskyy ${ }^{2}$, Viktoria Romanchuk2, Igor Samsin ${ }^{3}$
}

https://doi.org/10.23939/chcht13.01.101

\begin{abstract}
The organic waste was evaluated to be used for the biogas production in compliance with an acute need to reduce the consumption of traditional energy resources. The possibility of using organic waste (corn, straw, branches, fallen leaves, potato peelings) for the biogas production was experimentally confirmed. The influence of the initial fractions size and the temperature on the biogas yield has been studied. The yield of biogas produced from potato peelings was found to be the highest one.
\end{abstract}

Keywords: potato peelings, corn, fallen leaves, biogas.

\section{Introduction}

The production and use of biogas energy is one of the important sectors of renewable energy sources (RES) in the world. In a number of countries, bioenergy has taken an important part in the energy balance. Denmark, for example, accounts for more than $7 \%$ of bioenergy, Austria $-12 \%$, Sweden $-21 \%$, Germany - more than $24 \%$. The latter is the leading producer of biogas in the European Union. Annually in the EU, $14 \%$ of the total energy is received from biomass. The European biogas plant market is evaluated at 3 billion dollars and should grow to 25 billion by 2020 . At the same time, $75 \%$ of biogas is produced from agricultural waste, $17 \%$ - from organic waste of private households and enterprises, and $8 \%$ - from sewage treatment plants [1].

Today biogas technologies, which are based on anaerobic fermentation of the initial product, are operating in more than 65 countries of the world [2], namely in the USA, France, Great Britain, China, India and others, for the production of electricity from agricultural and livestock waste, food industry waste, selected household waste (food, paper, etc.), energy-rich plants (corn, grass, etc.). The total

\footnotetext{
${ }^{1}$ National Aviation University

1, Kosmonavta Komarova Ave., 03058 Kyiv, Ukraine

${ }^{2}$ Lviv Polytechnic National University

12, S.Bandery St., 79013 Lviv, Ukraine

${ }^{3}$ Khmelnitsky University of Management and Law,

8, Heroiv Maidanu St., 29000 Khmelnitsky, Ukraine

*lenyo@ukr.net

(C) Pavliukh L, Boichenko S., Onopa V., Tykhenko O.,

Topilnytskyi P., Romanchuk V., Samsin I., 2019
}

amount of biogas plants (BP) in Europe exceeds 11,000; 7,200 of which are located in Germany [2].

According to the European Commission's forecast regarding energy generation from the renewable sources, in 2020, the share of electricity from biogas in the EU will be $8 \%$, which will improve the contribution of small hydroelectric power plants, geothermal and solar energy. In opinion of analysts, the biogas market will continue to grow rapidly, replacing other energy sources in the overall structure of the energy balance of various countries [2, 3].

The economic valuation of using biogas cannot be determined quantitatively, because unlike fossil fuels, biogas is not sold in the local market and does not have a standard market price. Thus, the biogas value is approximated and based on the cost of boiler installation and maintenance. The practical use of biogas solves a number of environmental, social and energy problems, proves that this fuel is more economical than fossils. At the same time, there are a number of biotechnological problems associated with the launch and operation of biogas complexes that have been solved in the world by creating national scientific-technical programs and granting discounts for entrepreneurs who represent these technologies.

The level of biogas technologies implementation in Ukraine remains unsatisfactory due to the specific climate (sharply continental climate, cold nights and frosts in the winter up to $253 \mathrm{~K}$ ) and lack of scientific and technical policy in this area. However, there is a possibility to improve the situation using the experience of the EU countries. In 2012, a tender for the creation of a state standard for biogas, won by the Institute of Renewable Energy of the National Academy of Sciences of Ukraine [4], was held in Ukraine.

Since the construction of BP in Ukraine is important, there is an urgent need for further studies on the conversion of waste and biomass to biogas, taking into account the national requirements of consumers in the domestic market. Ukraine has a large agricultural potential and, accordingly, the opportunity to obtain raw materials for the creation of this type of biofuel, which can significantly influence the energy dependence of the country and the conservation of energy resources in general. 
The potential for biogas production

\begin{tabular}{|l|c|c|}
\hline Sources & Total volume of waste, $\mathrm{t} \cdot 10^{3}$ & Potential production of biogas, $\mathrm{mln} . \mathrm{m}^{3} / \mathrm{year}$ \\
\hline Total in Ukraine, including & 39727 & 9545 \\
\hline Sugar refineries & 23264 & 976 \\
\hline Breweries & 1017 & 122 \\
\hline Alcohol-containing plants & 2705 & 117 \\
\hline Livestock farms & 15432 & 386 \\
\hline Pig farms & 5657 & 160 \\
\hline Poultry farms & 4722 & 378 \\
\hline Corn silage & - & 7406 \\
\hline
\end{tabular}

The quantum of solid domestic waste in Ukraine in 2016 was $49 \mathrm{mln} . \mathrm{m}^{3}$ or about $11 \mathrm{mln} . \mathrm{t}$ (excluding the temporarily occupied territories of the Autonomous Republic of Crimea and the city of Sevastopol) [3], among which there is a significant share of organic waste. The average value of generated waste is $\sim 250$ $300 \mathrm{~kg} /$ year and this value tends to increase [3]. The potential for biogas production in the agro-industrial complex of Ukraine is presented in Table 1 [2]. According to experts estimation, when one ton of organic residues burns, about $9 \mathrm{~kg}$ of smoke microparticles, consisting of dust, nitrogen oxides, carbon monoxide and carcinogenic compounds, are formed. The process of atmospheric air poisoning taking place during organic waste burning is called ecocide [5].

In addition to direct damage to health, the burning of organic waste leads to the extermination of useful soil insects, destroys the fertile layer, where plant remains, soil microorganisms, seeds and roots of grassy plants are burned, damages the lower part of trees and shrubs.

Experts count that processing of 120 million tons of organic waste in a dry form can produce 3675 billion $\mathrm{m}^{3}$ of biogas [1]. Nowadays Ukraine produces less than 20 billion $\mathrm{m}^{3}$ of natural gas, and in 2017 the demand was 31.9 billion $\mathrm{m}^{3}[6]$.

Under the reduction of production activity and the rising cost of traditional types of fuel (coal, oil products, natural gas, etc.), the potential of organic, animal waste, plant residues of agricultural production, solid waste as a raw material for biogas production will increase significantly and, if not completely, at least partially, will meet the country's energy needs. Environmentalization of economic activity requires structural and technological restructuring of the energy complex management based on the transfer of innovative, energy-saving, environmental friendly technologies.

Biodegradable organic wastes are fully used during their processing as an alternative source of energy. As a result, the sanitary conditions of the territory are improved, the pathogens of infectious diseases are annihilated, the bad smell of rotting plants and weed seeds is destroyed. Moreover, the valuable high quality mineral fertilizers with a high content of humus are formed [7-9]. Organic and mineral remains after biogas production are much better to be used as complex fertilizers for agriculture compared with other ones (manure, garbage, peat and chemicals) [9-11]. They do not have adaptation period and do not contain pathogenic flora but have an active microflora that promotes the intensive plant growth. Due to their form the fertilizers begin to ferment immediately after the introduction into the soil. Studies [12-15] confirmed the effectiveness of plant waste (wheat and corn silage, Sudan grass) and livestock (manure of pigs and cattle) for the production of biogas.

The main trends in the development of bioconversion systems are determined by the requirements of environmental protection and can be achieved through the production of biogas as an alternative source of energy. The production and composition of biogas is determined by a significant number of factors, but basically it depends on the composition of raw materials [16]. The biogas composition is (wt \%): methane 50-70; carbon dioxide 30-40; hydrogen 5-10; small amounts of nitrogen, water vapor and hydrogen sulfide [17].

The problem of waste conversion into biogas and fertilizers is solved in the world via fermentation of organic matter in the methane reservoir under anaerobic conditions [18-29].

The anaerobic decomposition of organic matter is carried out by two main groups of microorganisms. The first group is heterotrophic acid-forming bacteria, which hydrolyze (decompose) complex organic compounds (proteins, fats, carbohydrates) into monomers by enzymes and use them to form low molecular acids, carbon dioxide, ammonia, hydrogen sulfide and water. The second group of anaerobic organisms is metamorphic bacteria, which use only low molecular organic substances, namely exchange products of acid-forming bacteria. Methane fermentation of organic substances forms ammonia, methane (biogas), free nitrogen, carbon dioxide and water [30]. 
The heat power of organic substances can be converted into methane and hydrogen by more than $80 \%$. The heating value of biogas is on average $25 \cdot 10^{3} \mathrm{~kJ} / \mathrm{m}^{3}$ and varies depending on the carbon dioxide content. Properly treated biogas (with a sufficient degree of purification) is an analogue of natural gas, but in contrast to it, biogas is a renewable and environmental friendly energy source. Therefore, biogas can be used not only as an automotive fuel, but also for the production of heat and electricity.

The production of bio-gas and industrial wastewater is a promising way to solve the following important environmental, economic and social problems: independence from traditional fuels; the use of surplus quantum of garbage; improvements in the state of the biosphere; supply of consumers with alternative energy sources; development and implementation of the modern energy technologies in accordance with the Energy Strategy of Ukraine by 2035.

The aims of this study are: i) to determine the possibility of using widespread organic waste (corn, straw, branches, fallen leaves, potato peelings) for biogas production; ii) to study the effect of raw materials fraction size and temperature on biogas formation.

\section{Experimental}

The experiment consisted of three stages: the first stage was carried out without additional processing of raw materials; during the second stage the organic materials with an increased surface area of the particles were used, and the third stage was devoted to the study of the temperature effect on the biogas yield.

First stage. The raw materials (corn waste, straw, branches, fallen leaves and potato peelings) were used without further processing. To collect gas we used a vessel by volume of $1.5 \mathrm{dm}^{3}$ with a rubber cork and a gasescape tube. One end of the tube was situated over wet biomass, and an elastic gas collector was connected to the second one. All connections were hermetical. The vessel contained $0.5 \mathrm{~kg}$ of biomass and $0.5 \mathrm{dm}^{3}$ of warm water (313-323 K). An excess of water was poured out after $4 \mathrm{~h}$.

The experiments were carried out at three temperature regimes: 288-291 K; 291-293 K and
293-296 K. The diameter of the gas collector was measured every 3-4 days, until the constant value. At the end of the experiment the obtained biogas was tested for combustion and then used in the laboratory. The experiment was repeated three times.

Second stage. The experimental conditions were the same as for the first stage. The difference was that the biomass was ground to a fraction of $0.5-1 \mathrm{~mm}$.

Third stage. A reservoir (plastic vessel of $1.5 \mathrm{dm}^{3}$ by volume) with a rubber cork and gas-escape tube was loaded with a grinded biomass (fraction of $0.5-1 \mathrm{~mm}$ ) and warm, settled water (without chlorine) in a ratio of $1: 1$, $\mathrm{v} / \mathrm{v}$. To neutralize the acidic medium, a small amount of lime was added to the biomass. The vessel was not completely filled (the space over the mixture was $5 \mathrm{~cm}$ ). Then it was placed in the heat chamber, where a temperature of $313 \mathrm{~K}$ was maintained. The evolution of gas was already observed during the first week.

\section{Results and Discussion}

Fig. 1 represents the experimental results obtained during biogas production from one kilogram of different raw materials for a certain period (first stage).

It is obvious that the biogas generation from all kinds of investigated waste was uniform throughout the entire experimental period. Potato peelings, corn waste and fallen leaves were the most productive in terms of biogas production.

The obtained data confirm the dependence of the biogas yield on the dry matter content in the substrate (Table 2).

Since potato peelings have a dry matter content of $88 \%$, corn waste $65 \%$ and fallen leaves $40 \%$ [31], then the yield of biogas produced from potato peelings is higher compared with corn and fallen leaves.

It is well-known that straw and corn utilization is widely used for biogas production in the world, but the results of our experiments showed that the production of biogas from fallen leaves $\left(63.13 \mathrm{~m}^{3} / \mathrm{t}\right)$ is higher compared with that from straw $\left(57.01 \mathrm{~m}^{3} / \mathrm{t}\right)$ and somewhat lower than from corn waste $\left(81.81 \mathrm{~m}^{3} / \mathrm{t}\right)$, while from potato peelings biogas production has the highest value $\left(91.66 \mathrm{~m}^{3} / \mathrm{t}\right)$.

Table 2

Dependence of the biogas yield on the substrate content

\begin{tabular}{|c|c|c|c|}
\hline Raw material & Dry matter, $\%$ & Organic dry matter, $\%$ & Biogas yield, $\mathrm{m}^{3} / \mathrm{t}$ \\
\hline Potato peelings & 88 & 94.7 & 91.66 \\
\hline Corn waste & 65 & 98 & 81.81 \\
\hline Fallen leaves & 40 & 89.2 & 63.13 \\
\hline
\end{tabular}




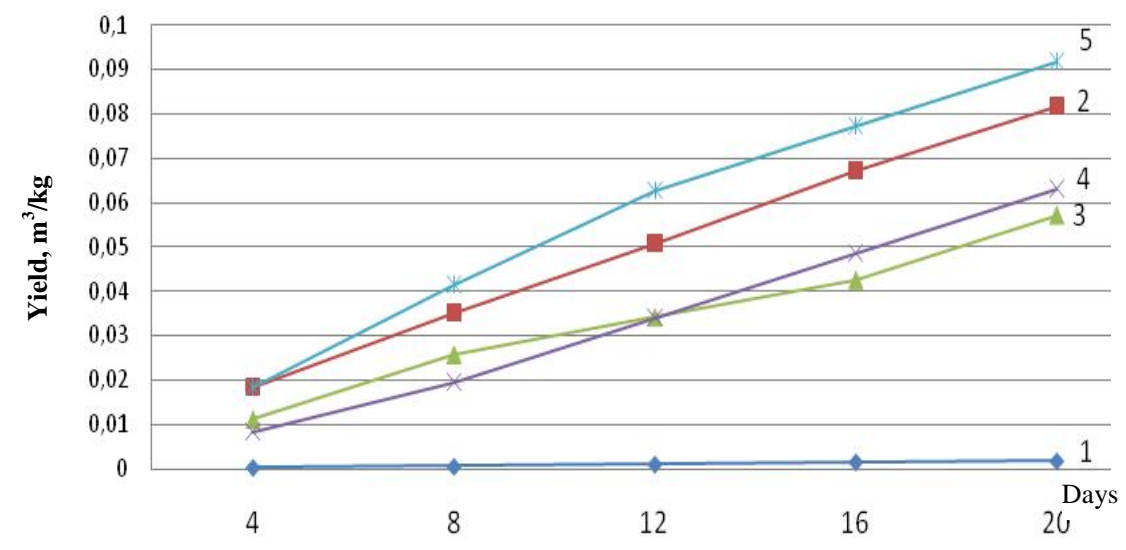

Fig. 1. The yield of biogas from different raw materials: branches (1); corn waste (2); straw (3); fallen leaves (4) and potato peelings (5)

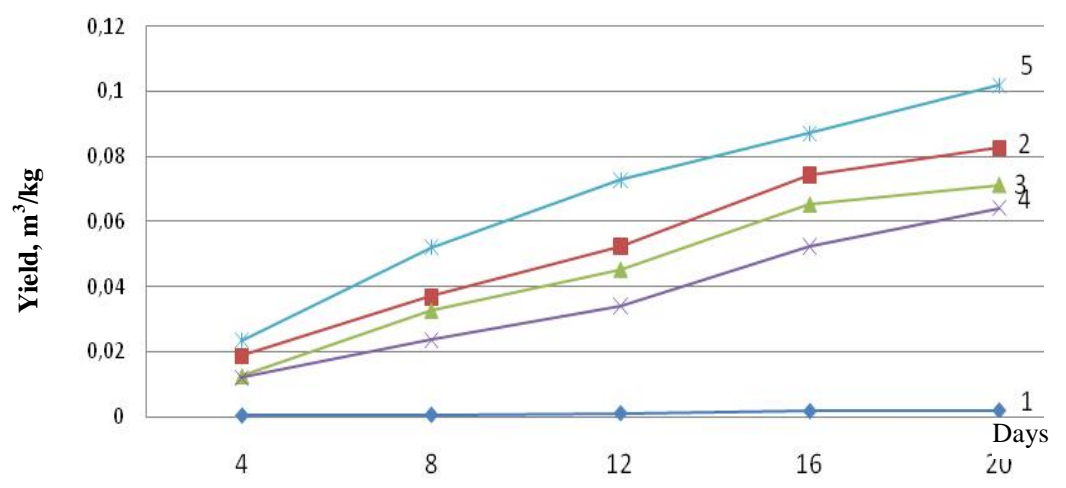

Fig. 2. The yield of biogas from grinded fraction of different raw materials: branches (1); corn waste (2); straw (3); fallen leaves (4) and potato peelings (5)

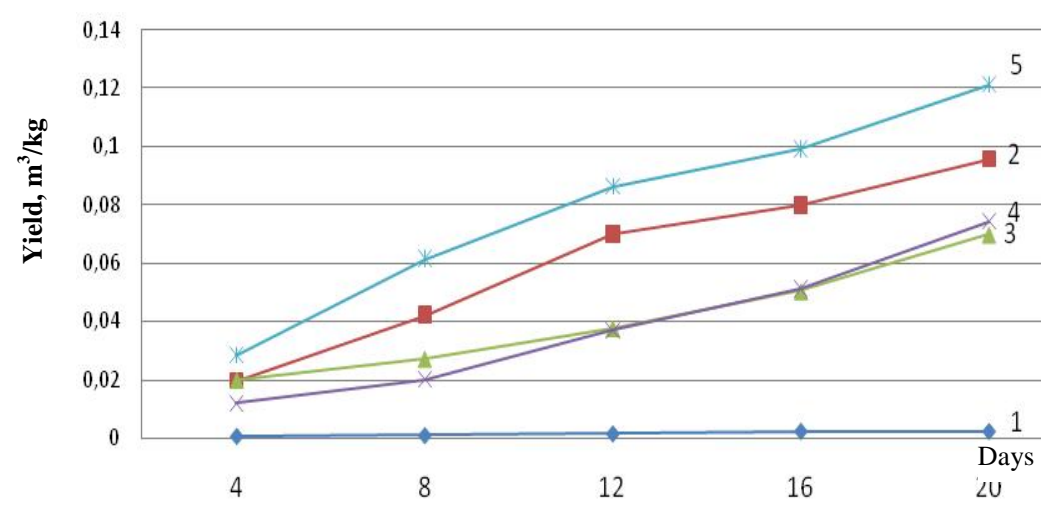

Fig. 3. The yield of biogas produced at $313 \mathrm{~K}$ from different raw materials: branches (1); corn waste (2); straw (3); fallen leaves (4) and potato peelings (5)

Table 3

\section{Effect of $\mathrm{C} / \mathrm{N}$ ratio on biogas production}

\begin{tabular}{|l|c|c|c|}
\hline \multicolumn{1}{|c|}{ Substrate } & $\mathrm{N}, \%$ & $\mathrm{C} / \mathrm{N}$ & Biogas yield, $\mathrm{m}^{3} / \mathrm{t}$ \\
\hline Fallen leaves & 1.0 & 50.0 & 63.13 \\
\hline Corn waste & 1.2 & 56.6 & 81.81 \\
\hline Potato peelings & 1.5 & 25.0 & 91.66 \\
\hline
\end{tabular}


Fig. 2 represents the results of biogas production using a grinded fraction $(0.5-1 \mathrm{~mm})$ of different raw materials for a certain period (second stage). The larger the interaction area and the more fibrous the substrate, the higher biogas yield. Under such conditions it is easier and faster for bacteria to decompose the raw material. Moreover, the grinded raw material affects the amount of gas produced during the fermentation period. The shorter this period, the better the material must be ground. The most effective for biogas generation were potato peelings, corn waste and fallen leaves.

Since the aim of the third stage of the experiments was to study the effect of high temperature on the bacteria activity, we carried out investigations at $313 \mathrm{~K}$. The higher temperatures were not tested because bacteria were perishing. The highest yield of biogas was found to be $0.12 \mathrm{~m}^{3} / \mathrm{kg}$ for potato peelings (Fig. 3). Corn waste and fallen leaves also show good results. So, the elevated temperature has a positive effect on the yield of biogas produced from all types of raw material except branches.

The balanced ratio of nutrient macro- and microelements is necessary for the stable fermentation process. Among microelements the most important are carbon and nitrogen: carbon is a constructive basis of biogas; nitrogen is needed to form enzymes participated in bacteria metabolism. Therefore, the main factor for the stability of methane fermentation is the carbon/nitrogen ratio $(\mathrm{C} / \mathrm{N})$ in the substrate. If this ratio is too high, carbon cannot be completely processed owing to the insufficient metabolism, and as a result, the biogas yield decreases. If there is a high content of $\mathrm{N}$ and negligible content of $\mathrm{C}$, the excess nitrogen can form a large amount of ammonia, which, even at small concentrations, slows down the bacteria growth and can even lead to complete destruction of the entire population of microorganisms. Therefore, in order to ensure the process stability, the ratio of $\mathrm{C} / \mathrm{N}$ should be in the range of 10-30 [32,33].

The dependence of the biogas yield on the $\mathrm{C} / \mathrm{N}$ ratio in the substrate for potato peelings, corn waste and fallen leaves is shown in Table 3. One can see that the $\mathrm{C} / \mathrm{N}$ ratio for potato peelings is equal to 25 and the same raw material shows the highest biogas yield.

If we take into account that 1 person consumes 90 $100 \mathrm{~kg}$ of potato per year, then it is possible to obtain $19 \mathrm{~m}^{3}$ of biogas from potato peelings; it is enough to cook for 1 person during a month. Potato average yield is 1520 tons per hectare, and the amount of potato peelings from this mass is sufficient $(180-220 \mathrm{~kg}$ of peelings is obtained from $1 \mathrm{t}$ of potato) to get $300 \mathrm{~m}^{3}$ of biogas. Such volume of biogas is enough to cook for 3 persons during one year.

$7000-8000 \mathrm{~kg}$ of green mass are formed from 1 ha of corn. About $610 \mathrm{~m}^{3}$ of biogas obtained from this mass is enough to cook for 3 people during two years, or to heat a house with the area of $100 \mathrm{~m}^{2}$ during 2 months in the winter.

$1800-2000 \mathrm{~kg}$ of straw is obtained from 1 ha of wheat. The amount of biogas produced from this straw is $115 \mathrm{~m}^{3}$; this volume is sufficient to cook for 3 persons during 3 months.

During spring or autumn cutting of trees in the suburban areas about $100-120 \mathrm{~kg}$ of branches are got from 10-12 trees. Taking into account that in such a case only $1.7 \mathrm{~m}^{3}$ of biogas may be produced, this source of raw materials for biogas production is inappropriate.

On average $1500-1800 \mathrm{~kg}$ of fallen leaves are accumulated in the autumn on 1 ha of the park area. About $120 \mathrm{~m}^{3}$ of biogas can be obtained from this mass; this is sufficient to cook for 3 persons during 3 months. One more important advantage is the reduction of harmful emissions into the atmosphere. The leaves, which remain to form humus, during decomposition evolves methane, which is twenty times stronger greenhouse gas than carbon dioxide is. Thus, the fallen leaves as a fuel have a double positive effect on the environment and they are a renewable energy source that will be formed annually.

The cost-effectiveness of biogas production from waste consists in the fact that there is no need for preliminary collection, organization and storage of waste, since it is known how much and when waste is received. The production of biogas is possible in different installations; especially it would be effective in agroindustrial complexes, where there is a possibility of a complete ecological cycle. Biogas can be used for lighting, heating, cooking, for actuating mechanisms, generators, etc.

\section{Conclusions}

So, the prospects of using waste for biogas production have been confirmed. Among the investigated organic wastes the potato peelings, corn waste and fallen leaves were found to be the most productive in relation to the biogas yield $\left(91.66,81.81\right.$ and $63.13 \mathrm{~m}^{3} / \mathrm{kg}$, respectively). The positive influence of the raw materials grinding and elevated temperatures was shown. We propose to use fallen leaves in the city boilers. This method is environmentally safe, and gives the possibility to reduce the emission of greenhouse gases such as methane into the atmosphere.

\section{References}

[1] http://agravery.com/uk/posts/show/12

[2] http://www.epravda.com.ua/columns/2013/07/3/383399

[3] http://zakon0.rada.gov.ua/laws/show/820-2017-\%D1\%80

[4] https://tender.me.gov.ua/EDZFrontOffice/ 
[5] Serbin V.: Netradytsiini ta Ponovliuvani Dzherela Energii v Systemakh THP. DonDABA, Makiivka 2003.

[6] https://dt.ua/ECONOMICS/u-2017-roci-vikoristannyaprirodnogo-gazu-v-ukrayini-skorotilos-na-4-267935_.html. [7] Karpenko V., Reutskaya N., Yhnatova T.: Technolog. Bioenergetika, 1988, 3, 97.

[8] Karpenko V., Chernyshenko D.: Ukraina: Liudyna, Suspilstvo, Pryroda, 1995, 5, 25.

[9] Karpenko V., Popovych M.: Ukraina: Liudyna, Suspilstvo, Pryroda, 1995, 6, 112.

[10] Karpenko V., Maslych V.: Ukraina: Liudyna, Suspilstvo, Pryroda, 1995, 7, 7.

[11] Karpenko V., Dehtiar D.: Mizhnarod. Ecol. Forum "Dovkillia", Ukrayna, Kyïv 2010, 276.

[12] Naik N., Tkachenko E. et al.: The Anaerobic Digestion of Organic Municipal Solid Waste in California. University of California, Berkeley 2013.

[13] House H.: Proceed. London Swine Conference "Today's Challenges...Tomorrow‘s Opportunities”. London, 3-4 April 2007, 119-128.

[14] Rittmann B.: Biotechnol. Bioeng., 2008, 100, 203. https://doi.org/10.1002/bit.21875

[15] Deublein D., Steinhauser A.: Biogas from Waste and

Renewable Resources. Wiley-VCH 2008.

[16] Baader V., Done Ye, Brennderfer M. Byohaz: teoryja y praktyka. Kolos, Moskwa 1982.

[17] Karpenko V., Malashenko Ju., Muchnyk F., Jastremskaja L.: VII syezd ukraynskoho mykrobyolohycheskoho obshchestva, Ukraine, Chernovcy-Kyev 1989, 120.

[18] Igoni A., Eze C. et al.: [in:] Proc. 1st Annual Conference of Science and Technology Forum, 2005, 146, 67.

[19] Zhang Y., Banks C. et al.: J. Environ. Manage., 2012, 104, 166. https://doi.org/10.1016/j.jenvman.2012.03.043

[20] Banks C., Salter A. et al.: Resour., Conserv., Recy., 2011, 56,

71. https://doi.org/10.1016/j.resconrec.2011.09.006

[21] Banks C., Chesshire M. et al.: Waste Resour. Manage., 2011,

164, 141. https://doi.org/10.1680/warm.2011.164.3.141

[22] U. O. GLASGOW, Safety \& Environmental Protection

Services Guidance Note Animal By-products (ABPs). University of Glasgow, Glasgow 2015.

[23] Themelis N., Kim H.: Waste Manage. Res., 2002, 20, 234. https://doi.org/10.1177/0734242X0202000304
[24] Demirbas A.: Energ. Source A, 2008, 30, 101. https://doi.org/10.1080/00908310600626788

[25] Ferrer I., Ponsa S., Vazquez F., Font X.: Biochem. Eng. J., 2008, 42, 186. https://doi.org/10.1016/j.bej.2008.06.020

[26] Rao P., Baral S., Ranjan D., Srikanth M.: Renew. Sustain. Energ. Rev., 2010, 14, 2086.

https://doi.org/10.1016/j.rser.2010.03.031

[27] Angelidaki I., Karakashev D. et al.: Methods in Enzymol., 2011, 494, 327. https://doi.org/10.1016/B978-0-12-3851123.00016-0

[28] Hejnfelt A., Angelidaki I.: Biomass Bioenerg., 2009, 33, 1046. https://doi.org/10.1016/j.biombioe.2009.03.004

[29] Ostrem K., Millrath K., Themelis N.: $12^{\text {th }}$ North American Waste to Energy Conference, Savannah, Georgia, May 17-19 2004, 265. https://doi.org/10.1115/NAWTEC12-2231

[30] Mustafaa M., Calayb R., Románc E.: $8^{\text {th }}$ Int. Cold Climate HVAC Conference, 2016, 310.

[31] http://www.biteco-energy.com/vyhod-biogaza-iz-razlichnogosyrya- $2 /$

[32] [https://www.sworld.com.ua/konfer40/41.pdf]

[33] https://energypedia.info/wiki/Nitrogen-content_and_C/Nratio_of_Organic_Substrates

Received: February 28, 2018/Revised: April 25, 2018 / Accepted: September 15, 2018

\section{РЕСУРСНИЙ ПОТЕНЦАЛ ДЛЯ ВИРОБНИЦТВА БІОГАЗУ В УКРАЇНI}

Анотація. Проведено оцінку використання органічних відходів для виробниитва біогазу за умов гострої необхідності скорочення споживання традииійних енергоресурсів. Експериментально підтверджена можливість використання органічних відходів (кукурудзи, соломи, гілок, опалого листя, картопляного лушииння) для виробництва біогазу. Досліджено вплив подрібнення фракції сировини та температурного режиму на вихід біогазу. Встановлено, щзо найбільший вихід біогазу з картопляного лушииння.

Ключові слова: картопляне лушпиння, кукурудзиння, опале листя, біогаз. 